\title{
Russia and its shared neighbourhoods: a comparative analysis of Russia-EU and Russia- China relations in the EU's Eastern neighbourhood and Central Asia
}

\section{Vsevolod Samokhvalov}

To cite this article: Vsevolod Samokhvalov (2018) Russia and its shared neighbourhoods: a comparative analysis of Russia-EU and Russia-China relations in the EU's Eastern neighbourhood and Central Asia, Contemporary Politics, 24:1, 30-45, DOI: 10.1080/13569775.2017.1408171

To link to this article: https://doi.org/10.1080/13569775.2017.1408171

Published online: 19 Dec 2017.

Submit your article to this journal 주

Q View related articles $\sqsubset$

View Crossmark data $[\pi$

Citing articles: 1 View citing articles $[\pi$ 


\title{
Russia and its shared neighbourhoods: a comparative analysis of Russia-EU and Russia-China relations in the EU's Eastern neighbourhood and Central Asia
}

\author{
Vsevolod Samokhvalov \\ Centre for International Relations Studies, University of Liege, Liège, Belgium
}

\begin{abstract}
This article examines the conditions under which great powers succeed or fail to shape a cooperative security agenda in their shared neighbourhoods. It compares Russia's interactions with the EU and with China in their respective shared neighbourhoods: the EU's Eastern Neighbourhood region and Central Asia. The article applies a synthetic framework. It analyses how the interplay between three factors - ideas, capabilities and circumstantial factors such, as the personalities of leading politicians, - shape the process of interaction between great powers. It starts from a comparison of the images of the two regions in Russia's mind-set because such images provide cognitive lenses through which powers make sense of political developments in shared neighbourhoods. The article then moves to show how change in the balance of power (soft and hard) created enabling conditions for competition/collaboration. Finally, the article shows how specific circumstantial factors led to or shaped the RussianEuropean conflict. At the same time, similar factors prevented Russian-Chinese conflict in Central Asia.
\end{abstract}

\section{KEYWORDS}

Russia; European Union; shared neighbourhood; identity; foreign policy; China; Central Asia

\section{Introduction}

This article seeks to examine conditions under which great powers succeed or fail to shape a cooperative security agenda in their shared neighbourhoods. To explore these conditions, it compares two dyads of great powers interacting in their respective neighbourhoods: Russia and the EU and Russia and China in their respective shared neighbourhoods, that is, the EU's Eastern Neighbourhood region and Central Asia. In particular, the article asks how Russian-European interactions in the shared neighbourhood region have degraded from a collaborative pattern into an open conflict, while Russian-Chinese interactions in Central Asia have evolved from co-existence into competition, but did not slide into conflict. To answer this question, and in line with the overarching rationale and framework of this special issue, the article will employ a loose synthetic analytical framework as elaborated by Goetz (2016). Goetz has shown that major explanations - geopolitics, identity, internal politics or individual factors such as Putin's personality - taken individually cannot explain Russian foreign policy, especially its variance across time. Instead, 'scholars 
need to investigate the interrelations of different factors and to develop synthetic accounts that specify how external factors are related to internal determinants, how material and ideational forces interact and how the interplay between agents and structures influences Russia's near abroad policy' (Goetz, 2016, pp. 2-3).

Drawing on this conceptualisation, Goetz suggests a multi-layered analytically eclectic framework that resonates with this special issue's focus on scope conditions related to power (a)symmetry, neighbourhood strategies and perceptions of the relative importance of the shared neighbourhood. The interaction between these factors should be studied through within-case comparison and process-tracing of the long-term evolution of Russian foreign policy. This analytical framework can help to explain degradation of Russian-European relations and the conflict in the EU's Eastern neighbourhood, as well as its less conflictual Sino-Russian relations. Goetz effectively brackets the question of commensurability between various theories/elements employed in such a research design, but makes up for it by providing a detailed analytical strategy which allows to show the interplay between various factors. This article will draw on Goetz' strategy and assumptions, but will adapt it to the framework of this special issue.

First, drawing on social constructivism (Hopf, 2002), the article will rely on textual analysis to identify the importance of the two neighbourhoods in the Russian identity and thus address the perceptions of the shared neighbourhood. Analysed texts include those books which were obligatory for consumption by today's Russian elites in their most 'impressionable' years, such as during their teenage and early adulthood period (1960-1970s). ${ }^{1}$ It will analyse school and university textbooks on history as well as texts which were voluntarily consumed by Soviet youth - the most popular fiction books and movies. By looking at recurring messages, the article will identify the role of the Black Sea region and Central Asia in the Russian identity. ${ }^{2}$ In particular and in line with the overarching rationale of the issue, it will explore what kind of 'Others' Europe and China constituted in Russia's identity, how the two regions were envisioned and whether those ideas condition Russia's contemporary willingness to pursue any policy in the region, i.e. region-building or region-spoiling.

In section 2, the article engages in a process-tracing of Russian-European and SinoRussia interactions in their shared neighbourhood in light of evolving power dynamics. This step modifies a neoclassical realist approach in tune with the abovementioned rationale of the special issue. Firstly, it pays more attention to the soft power of Europe than neoclassical realism. Even though neoclassical realists include ideational factors in their analyses, they clearly treat the balance of material capabilities as the primary factor and attribute to other factors the status of intervening variables (Rose, 1998, pp. 146-147). This is not to challenge the claim that material capabilities matter, but to stress that there is no proof that material capabilities matter more than ideas in Russian-European relations. Quite to the contrary, even some neo-realist discussions of EU-Russia relations pointed out that soft power and ideas sometimes matter more (Romanova, 2012).

Second, treating identity as an intervening variable implies that it has a fixed value which may only affect decision-makers in a certain way. Less attention is paid to the fact that the process of interaction and the shifting balance of power can change identity and, subsequently, the pattern of interaction (Clunan, 2009). The neorealist approach under-emphasized this fluid nature of identity and the link between soft and hard power. So the second section of the article will analyse how the process of interaction 
in the two dyads and change in the balance of power affected the realm of ideas and created enabling conditions for conflict/coopetition.

I will show how the balance of (both soft and hard) power was gradually changing and led Russia and Europe from reunion to uneasy collaboration through co-opetition to competition. It will also be argued that strong (even if declining) soft power of Europe prevented conflict between the two up until 2014. By contrast, China offered Moscow an agenda for global interaction, and, in exchange, Russia turned blind eye to Chinese penetration into Central Asia.

The third and fourth sections will show how specific strategies in the shared neighbourhood and events on the ground generated conflict between Russia and the EU and alleviated tensions in Sino-Russian relations. In particular, the article argues that it was the personality of Vladimir Putin, his vision to redefine Russia's greatness in Western terms by launching his own regional integration project and his special sentiment towards the Black Sea region, which shaped today's Russian-European crisis and the conflict in the shared neighbourhood. At the same time, the personal qualities of the Chinese President Xi Jinping, who cultivated close personal relations with Putin, prevented any conflict between Russia and China in similar circumstances i.e. when China launched an ambitions regional project in Central Asia and effectively challenged Russia's symbolic domination in the region. However, ideas can still better explain why, after China challenged Russia's symbolic domination in the region, Moscow preferred to conduct a non-conflictual region-spoiling tactics rather than to have a head-on collision with Beijing. The conclusion summarises the findings and, in line with the third, normative objective of the special issue, indicates what could be done to prevent conflict and facilitate cooperation in both neighbourhood settings.

\section{The Black Sea Region and Central Asia in the Russian identity}

The Black Sea region, and more specifically Crimea, represents a unique place for Russians because it plays a central role in Russia's origin myth. Such important milestones of human evolution as the first camps of primitive people, the first agricultural villages, the first cattle-breeding settlements or the first Bronze Age slave-owning states were discovered only in the Black Sea region (Pankratova, 1947, pp. 4-13; Samokhvalov,2017; Zhukov, 1955, pp. 4, 26-27). The main official Soviet textbook on diplomacy argued that through this region 'the history of the nations of the world was organically linked to the past of the nations of the Soviet Union' (Potemkin, 1941, p. 25). No other region in the vast Russia periphery has ever been described in such terms.

A second, more specific feature which makes the Black Sea region important for Russia's identity is the fact that it is the place where Russia - in its various historical embodiments has become part of the European civilisation. Cultural and religious borrowings from the Eastern Roman Empire in the medieval period and the fact that the ports of the Black Sea were considered gateways to Europe have been an extremely important element for Russian identity and its belonging to Europe. In addition, the string of Russian-Ottoman wars in the 17th-19th centuries, resulting in numerous victories followed by intense diplomatic games, linked the region with Russia's great power status. This discourse has been reproduced in contemporary Russian media where Russia's great power status is predominantly linked to the signifier 'European great power' and most often articulated in the 
description of crises in the Balkans and Black Sea region. This idea that for being a great power Russia should interact with Europe provided it with strong soft power over Russia.

Last, but not least, two major spots inside the Black Sea region played a particularly important role in the ethno-national story of Russia. Russian historiography and textbooks frequently quote the famous sentence from one of the first medieval Slavonic chronicles that the medieval Principality of Kiev was the 'mother of Russian cities' and 'the cradle of three fraternal nations - Russians, Ukrainians and Belarusians'. The sacred core of this region is Crimea, which was always depicted in ethno-nationalist Russian colours. For instance, Sevastopol has regularly been described as the 'city of the ethno-national Russian glory' (gorod Russkoy slavy). Hence, the role of the Black Sea region is far more important than that of any other region of the vast historical territory of the Russian Empire. This importance of the region for Russian identity and quest for recognition by Europe created very special conditions for Russian-European the interaction.

Unlike the Black Sea region, Central Asia had been incorporated into the Russian Empire in the 16th century and therefore was not linked to Russia's origin myth. The period of Russian-British struggle for control of the region has been a comparatively short moment in its history. Additionally, Central Asian nations and their cultures displayed significant racial and cultural differences from the core Russian imperial nation, and Russian intellectuals treated Central Asia through the lens of European Orientalist discourse (Pandey, 2007). Moreover, managing vast empty Eurasian spaces was often described as a curse rather than a blessing (Hill \& Gaddy, 2012, pp. 9-25). In Russian fiction literature, the most popular Soviet blockbuster 'The White Sun of the Desert' featured Central Asia 'as the clean slate and a terra nullius at the imperial periphery' (Condee, 2009, p. 91), and highlighted the backwardness of Central Asia's Muslims (Gilespe, 2003, p. 127). This spirit was also present in mainstream cultural writings and political debates in the late 1980s (Singh, Chaterjee, \& Sengupta, 2014; Staples, 1993). As a result of this failure, multiplied by the trauma of the Afghan war, Russian strategic thinking perceived the region mostly as a problem rather than a prize.

Similarly, the Soviet political elite read China through the lenses of its underdeveloped periphery (Hopf, 1999). This generated a lack of interest and expertise in the region. In the 1990s, only a handful of specialists in Russia had some expertise on China, while the foreign policy agenda in the East was dominated by Euro-centrists (Titarenko, 2014, p. 11). To some extent this indifference was helpful in resolving a number of border disputes between the USSR and China. Even before the dissolution of the Soviet Union, representatives of three Central Asian republics of the USSR were included in the negotiations. This process played an important role later on when Russia and China met in the international arena.

Altogether, with the collapse of the Soviet Union, the two dyads entered into fundamentally different relationships: Russian relations with Europe were filled with inflated expectations of reunion in a sacred place of Russian identity - shared neighbourhood in the Black Sea. At the same time, Russian-Chinese relations were not charged with any expectations but rather prompted the two sides to carefully test each other in the process of interaction. 


\section{Power dynamics and identity change in the shared neighbourhood}

Even constructivists (Clunan, 2009; Hopf, 2002) and post-structuralists (Hansen, 2009) acknowledge that identities may change and evolve. The article proceeds therefore on the assumption that the above-described imagery of these regions may create some sort of ideational background. At the same time, change in the distribution of power can re-shape identities and re-constitute a gamut of thinkable policy options. In the case of the Black Sea region, it will be shown that the interaction with Europe and the rise of Russia's material capabilities and gradual decline of Europe's soft power resulted in a more competitive (albeit not conflictual) process of interaction between the two actors. Alternatively, Central Asia remained a problematic place in the Russian cognitive landscape and conditioned Moscow's indifference towards the region. This indifference allowed China to increase its political and economic presence in the region while maintaining good relations with Russia.

\section{Russian-European interaction in the Black Sea region}

As mentioned, the Black Sea region played a dual role in Russia's identity. On the one hand, it was the place of Russia's origin myth. On the other hand, it was the locus of Russia's belonging to Europe and the great powers. This duality shaped the trajectory of Russian foreign policy throughout the 1990s. Initially, Russia supported the secession of conservative pro-imperial enclaves in various republics in the post-Soviet space, i.e. Transnistria (Moldova), Abkhazia and South Ossetia (Georgia), as well as Nagorno Karabakh (Azerbaijan). What followed, however, was Russia's active engagement with European security structures in order to resolve these conflicts (Hill, 2012, p. 37). The soft powerof Europe was so high in the 1990s that Moscow the OSCE to deploy its missions in all conflict zones, even inside of Russian territory during the first Chechen war in 19951998. Moreover, Moscow refused to support the 1993 locally-driven separatist referendum in the Crimea and collaborated with the OSCE to resolve the crisis. However, the distribution of power would then affect which element of Russia's great power identity would prevail. For example, when criticised at home for 'giving away Crimea', President Yeltsin managed to neutralise radical nationalist opposition by arguing that national and religious sentiments should be subordinate to the question of interaction with other great powers and, by no means, threaten the survival of Russia (Samokhvalov, 2017, pp. 131-136). From this perspective, power asymmetry indeed leads to a more cooperative attitude of a weaker great power in a shared neighbourhood (Schunz, Gstöhl \& Van Langenhove, 2017).

In the case of Russian-European Union relations it is also Europe's soft power that prevented sudden ruptures in Russian-European relations when the balance of material capabilities changed. Even though Russia's material capabilities were growing, Moscow still sought the recognition of and an alliance with Europe. The EU, however, had far less soft power to exercise over Russia. Unlike the OSCE, which in the 1990s was seen as the embodiment of collaborative and inclusive idea of Europe, the EU in 2001-2005 was perceived as technologically advanced and socially progressive, but incompetent international actor in the making (Samokhvalov, 2017). Therefore, Moscow's mission was to empower and to educate the EU into becoming an independent great power. To 
achieve this goal, Moscow pursued a mix of cooperative and competitive policies in the Black Sea region. On the one hand, Moscow invited the EU to join Russia-led conflict-resolution processes in Moldova and Georgia. It also supported EU initiatives in these areas if they had previously been presented to and approved by Moscow (Samokhvalov, 2017, pp. 169-199). On the other hand, Moscow torpedoed each and every independent EU initiative, especially when it undermined Russian control on the ground. In the framework of this co-opetition, Moscow sought to 'socialize' the EU into creating a Black Sea security complex and recognising Russia as senior partner in the new region. President Medvedev wanted to formalise this arrangement by tabling a proposal on a European Security Treaty in June 2008, in which conflict resolution in the Black Sea region was placed in the centre (Wetiz, 2012).

The EU effectively refused to participate in the Russia-led regional security complex. For Moscow, it was a bitter disappointment that the EU blocked Putin's effort to resolve the Transnistrian conflict in 2003 and that it did not sufficiently consult Russia when preparing the recognition of Kosovo. By 2007, the EU had even lost its ability to exercise soft power over Russia, as Moscow lost any interest in discussing its further integration with the EU (White \& Feklyunina, 2014). However, as an expert in Russian identity has put it, Europe still remained the only political subject on the Russian cognitive horizon (Morozov, 2015). This strong presence of Europe prevented Russia from engaging into balancing acts with other actors or through broader regional institutions such multilateral Black Sea Economic Cooperation. Instead, Moscow sought to redefine the European project through its bilateral relations with EU members in order to gain their recognition (Marsh \& Rees, 2012, p. 90). In the course of the Russian-Georgian war in 2008, Moscow accepted French mediation and disregarded the President of the European Commission, José Manuel Barroso. This type of relationship was however deeply unstable, ultimately leading to dynamics that generated conflict, as considered in the next section. The period of interaction between Russia and European actors (OSCE, EU, European great powers) shows the interplay between identity and power. In the early 1990s, when Russia was extremely weak in terms of material capabilities, it behaved in an extremely cooperative way and made significant concessions to Europe. As Russia's material capabilities increased in the early 2000s, Moscow started considering more competitive options However, Europe's normative superiority (asymmetry in soft power) conditioned co-opetition between Russia and Europe in the Black Sea region. Fixation of the actors on each other resulted in the fact that they failed to produce multilateral regional institutions and did not allow to broaden the format of interaction which would have helped to alleviate tensions.

\section{Sino-Russian interaction in Central Asia}

Unlike Russian-EU relations in the Black Sea region, Russian-Chinese interaction in their shared neighbourhood has not been charged with inflated expectations or grand visions. In these conditions, the diplomatic practice inherited from the Soviet-Chinese negotiations on border demarcation played an important positive role. Russia - as legal successor of the USSR - had to follow through the package of Sino-Soviet agreements on settling border issues (Galenovich, 2017). However, part of these agreements were now to be implemented by three Central Asian republics - Kazakhstan, Kyrgyzstan and 
Tajikistan - bordering with China. Bilateral agreements turned into formal penta-lateral international negotiations in 1992. China sought to institutionalise this multilateral momentum and used security concerns to bring its counterparts to sign a declaration on confidence-building measures in the border areas. The declaration signed in April 1996 by the Shanghai-5 laid the foundation for setting up the Shanghai Cooperation Organisation (Aris, 2011, p. 3). The Russian presence in the region was fixed through what was called hegemon-sponsored regionalism (Alison, 2004, p. 468), with the three former Soviet republics joining post-Soviet Russia-led integration schemes, such as Commonwealth of Independent State and Collective Security Treaty Organisation. Even though most of these structures turned out to be virtual regionalism (Alison, 2008), Russia maintained its symbolic power over the region.

A second important factor that played a role in developing a collaborative pattern of interaction was the growth in trade between Russia and China. Chinese shuttle-trading was essential in maintaining life in the vast empty Asian part of Russia. In the 1990s, military cooperation between Beijing and Moscow helped the Russian military-industrial complex to survive (Gabuev, 2015, p. 3; Weitz, 2003). These developments increased the level of trust in Russian-Chinese relations. Additionally, they reconfirmed Russia's identity. Moscow remained a supplier of sophisticated industries while China was offering mostly consumption goods or low-skilled labour to the Russian Far East and Central Asia. A third important element was the emerging global agenda in Russian-Chinese relations. Both powers sought to challenge the global hegemony of the West. In 1997, Russia and China signed a Joint Declaration on a Multipolar World Order, where the two stated, 'no country should seek hegemony, engage in power politics or monopolise international affairs' (UN, 1997). It was a clear indication that Russia and China had become partners against US unilateralism (Molchanov, 2015, p. 117). In this framework, Moscow and Beijing worked together to condemn Western interventions and democracy promotion in the Balkans, Afghanistan, Iraq, Iran, Myanmar, Sudan, Zimbabwe and Kyrgyzstan (Chargynov, 2006). Both supported the use of force in suppression of protests in Uzbekistan and Kazakhstan (Saipov, 2015).

Given the number of major issues on which Russia needed Chinese support, Moscow pursued a policy of hedging in the region. It contained elements of engagement (to reap benefits) and resistance (when the cost was too high) (Korolev, 2016). For example, Russia did not oppose Chinese economic expansion into Central Asia. But when China sought to officially expand the mandate of the Shanghai Cooperation Organisation to include an economic dimension, Russia blocked it. This type of interaction was different from Russian-European relations. In the Black Sea region, Russia had superior material capabilities, while Europe still slightly prevailed in terms of soft power over Russia. So in the early 2000s, Russia used its ability to manipulate insecurity in order to try to 'socialize' Europe into recognising Russia as the great power responsible for the region. In Central Asia, Russia was facing a - in terms of material capabilities - growing presence of China. However, given the low value of Central Asia for Russia, Moscow 'traded' its control over Central Asia as a bargaining chip in order to receive Chinese support on global issues. In this way, serious change in the balance of material capabilities and geo-economic shift in the region did not provoke a conflict between Russia and China in Central Asia. Both these relationships were, however, unstable. 
This process of Sino-Russian interaction suggests that ideas matter. Soft power should be considered in both positive and negative terms. Positive soft power means attraction. But, some regions can have negative symbolic value where a great power is not willing to engage in any sort of region-building. Such a negative attraction allows some sort of a great power cooperation in the region, sometimes accompanied by shallow institutions. This arrangement is, however, quite unstable. Once development on the ground undermined Russia's identity narrative and its symbolic domination over the region, Moscow turned to region-spoiling by broadening the geographic scope of neighbourhood (from Central Asia to Greater Eurasia).

\section{Great power strategies and circumstantial factors in the Black Sea region ${ }^{3}$}

Russia and Europe entered the 21st century with a dangerous dynamic in the power balance. Russian material capabilities increased and the gap between Russia and Europe was closing. Europe's soft power declined noticeably. As the introduction to this special issue suggests, such power symmetry can lead to competition in the region. However, power symmetry only can still not explain why the crisis erupted as of 2014 as a result of EU-Ukraine trade agreement and why it has taken such a dramatic shape. Even in comparison with the Russian-Georgian war, Russia's annexation of Crimea exceeded all previous levels of escalation. To explain this escalation, additional circumstantial factors have to be taken into account.

The first circumstantial factor is the personality of leaders. Vladimir Putin is probably the first Russian President who wanted Russia to become a new 'Western-like' great power. New greatness was envisaged by Putin in terms of economic performance. However, this pursuit of greatness, defined in European terms, comprised serious underlying tensions. Putin linked the concept of economic development to that of competition and struggle (Putin, 2003). The EU's neglect in consulting Russia before the launch of its European Neighbourhood Policy and the Eastern Partnership made Russia read these regional policies as a tool for geopolitical control over the shared neighbourhood. Russia's competitive response was an attempt to launch its own regional integration project - the Eurasian Economic Union (EAEU).

Even though Russia's policies in the region were sometimes driven by a geo-economic rationale (Wigell \& Vihma, 2016), Moscow's activities around the EAEU show that it was more of an identitarian project (Kazharskiy, 2013). It is only identity (and not economic reasoning) which can explain why Moscow made significant economic and political concessions to the other founding members, Belarus and Kazakhstan (Dragneva \& Wolczuk, 2013), as well as to countries whose economies were only a fraction of that of Russia, namely Armenia and Kyrgyzstan. It is only the quest for recognition by Europe which can explain Russia's strenuous effort to start negotiations about close integration of the EU and the EAEU.

Another important personal feature of President Putin was his special sentiment towards the Black Sea region spotted by most of his biographers (Dawisha, 2014; Gessen, 2013; Hill \& Gaddy, 2012). His summer retreats at the Black Sea coast, where he received heads of state and government, made his dacha there the third capital of Russia after Moscow and Saint Petersburg (Latynina, 2013). In his speeches, Putin repeatedly stressed that Crimea was a unique place through which Russia belonged to Europe 
(Press Service, 2011). This special attention was buttressed by extensive pressure on Ukraine. As a result of this pressure, Ukraine extended basing rights for the Russian Navy in Crimea and adopted a non-bloc status. Additionally, thanks to the weak personality of Ukrainian President Yanukovych (another personal factor), Russia asserted its control over the Ukrainian intelligence services and Ministry of Defence. Given these concessions, Russian representatives, including Putin himself, started speaking about Ukraine as if Kyiv was ready to re-integrate with Russia or, at least, enter Eurasian Economic Union. This factor played an important role in Russian decision-making during the crisis.

Personalities also matter on the EU side, as in 2013-2015 the EU was represented towards Russia by policy-makers and politicians who were either not interested or not able to engage in dialogue with Russia. EU CFSP High Representative Baroness Catherine Ashton focused more on the Middle East than on the Eastern Neighbourhood. She preferred to communicate with Moscow via op-eds in Russian newspapers, which was seen as sign of disrespect. The President of the European Commission, Barroso, stated that 'Russia's inclusion in the talks on the EU-Ukraine Association Agreement is wholly unacceptable', which also escalated the competitive geopolitical logic in Russia (Sakwa, 2015, p. 73). In the absence of other voices, Polish Foreign Minister Sikorski and his Swedish colleague Bildt were most active and visible in the EU discussion about Ukraine. Unfortunately, they were perceived as part of the agressive Atlanticist and Russophobic axis in Europe. In this situation, a spark could sway the Russian leadership into a conflictual paradigm and that spark came from developments on the ground.

The second circumstantial factor was the revolution in Ukraine. Even though the Ukrainian revolution was driven by a broad coalition of forces, pro-European intellectuals remained its most visible constituency. The fact that it happened right after President Putin managed to sway Ukraine back towards Eurasian regionalism supported the belief that the 'Revolution of Dignity' was nothing else but a plot organised by Europe, which did not want to recognise Russia's attempt to become a normal great power. Russia's answer to this mirrored what it thought was the EU's action in the shared neighbourhood: launching its own hybrid counter-offensive in Ukraine. The course of the crisis reveals important elements of Putin's personal traits. Analyses of the decision-making process in the Crimean operation suggest that Putin did not consult anyone apart from his intelligence- and army-affiliated associates about the prospects of taking over Crimea (Bukkvoll, 2016). He did not consult economists, area studies specialists or lawyers to assesses potential costs and consequences. So the decision to annex Crimea was not about a cost-benefit analysis.

Unlike conflicts in Georgia and Moldova, Russia did its best to avoid bloodshed in the Crimea. The name of the 'Crimean' operation was the 'Polite People', and it was conducted by elite forces who tried not to use firearms while squeezing out the Ukrainian troops from Crimea. In February-March 2014 strong diplomatic pressure was applied to prevent Ukraine from resisting. The fact that Russia quickly moved to organise a referendum, immediately recognised it and incorporated Crimea, suggests it has a unique, sacred, meaning for Putin. Even at the peak of the Russian-Western stand-off in the Caucasus during the war in Georgia, Moscow refrained from annexation of break-away regions of Abkhazia and South Ossetia. Russia's intransigence towards keeping Crimea - despite huge economic and political losses - suggests that this annexation is linked to identitybased motives, i.e. those that go beyond rational choice or strategic calculations. 
Therefore, it is rather an identity-based explanation linked to Putin's own understanding of the sacred places that can explain such behaviour.

By contrast, in Donbas - which had no link to the sacred symbols of Crimea - Russia deployed only limited of its regular forces and chose not to annex the region. Instead, it provided limited support, which would allow the conflict to go on. The conflict in Donbas and Minsk-format negotiations were regarded as yet another tool for the 'socialization' of Europe. By sitting at the negotiating table for as long as possible - as has been the case for other conflicts - Russia seeks to gain Europe's acceptance of its great power status. Additionally, developments in the Black Sea region confirm the general conclusion of this special issue that (soft and hard) power symmetry is more likely to generate competition and create enabling conditions for conflict. From a counterfactual perspective, if Russia had had a less assertive President than Putin, it might not have gone down the path of escalation, however.

Even though identity and power create enabling conditions, one should keep in mind the role of circumstantial factors that trigger and, therefore, shape violent conflict. From a counterfactual perspective, if Ukraine had been represented by a more independent President, Kyiv might not have accepted Russian control over its security apparatus. This would not have given Moscow the illusion that Ukraine is a ripe apple ready to fall in Russia's hand (Wilson 2014). Even the most pro-Russian President Leonid Kuchma managed to prevent Russia's creeping penetration into the Black Sea in 2002-2003. Had Ukraine had a less incompetent and authoritarian President, there would have been less societal mobilisation against Yanukovych and a peaceful rally of pro-European intellectuals would not have turned into the 'Revolution of Dignity'. If in 2013 the EU had been represented by officials with a 'less Euro-Atlantic background' than Sikorski or Bildt, Russia might have considered other responses. ${ }^{4}$ So even though structural factors create major enabling conditions, it is circumstantial factors and a combination thereof that 'decide' whether conflicts emerge and how dramatic it is. I will now consider how the RussianEuropean conflict and other circumstantial factors affected Russian-Chinese relations in Central Asia.

\section{The Ukrainian crisis and Russian-Chinese relations in Central Asia}

Russia pursued a policy of hedging China, i.e. allying against the West and providing soft resistance and engagement in Central Asia. This policy would have been sustainable if the two regional systems were isolated from each other. But China had several opportunities to see that Moscow often treated it as a secondary partner while dealing with Europe. During the 2006 Russian-European-Ukrainian gas crisis, Moscow demonstratively launched a joint Russian-Chinese energy project. But once the conflict was settled, Russia dropped the project and sought to develop the Nord Stream project with Germany (Gabuev, 2015). As a result, Chinese experts concluded that Russia was using China mostly as a threat to Europe and did not value their relations. This undermined the general spirit of a fair Sino-Russian partnership in the international area created in the 1990s and removed any moral commitments China might have had towards Moscow. China started a massive unlicensed copying of Russian high-tech military production, so that Moscow had to stop selling its most advanced weapons. Having benefited from Russian support, the Chinese nuclear industry started to compete and overtake Russia out of the 
international nuclear energy market. Finally, Russia's preoccupation with the EU gave it a free ride in Central Asia, where China was shopping for energy, mining, and infrastructure projects (Gabuev, 2015, p. 3).

In 2013, President Xi Jinping openly challenged the symbolic Russian leadership in Central Asia by launching the Chinese project, One-Belt-One-Road, and its regional version for Central Asia, the Silk Road Economic Belt (SREB). The programme was announced during President Xi's visit to Central Asia. From a counterfactual perspective, such fundamental geopolitical shifts could have easily provoked conflict if another Chinese leader had paid less attention to Russia's sensitivity. However, a similar set of factors - skilfully used by China - prevented open conflict between Russia and China in Central Asia. First, China presented a logistical and developmental programme, rather than a geo-economic project. Importantly, Russia echoed this statement. Commenting on the Chinese SREB project, the Chairman of the Kremlin-affiliated Valdai Club, Bystritskiy, stressed that the Silk Road was merely a road from one point to another, 'while it was Russia who managed to transform the 'road' into 'territory', a settled productive civilization' (Bordachev, 2016, p. 3). In more specific terms, Kremlin-affiliated intellectuals argued that this is exactly what Russia wanted for the region, i.e. roads, labour migration and enterprises to give them jobs. ${ }^{5}$ At the same time, it was accepted that Russia remained a hard-security provider in the region. In such a way SREB in fact enhanced the existing perception of the region and was ontologically comfortable for Russia.

A second factor that prevented conflict was that the Chinese elite fully appreciated the role of personal relations between leaders and of rituals in those relations. ${ }^{6}$ Unlike European policy-makers, who sought to 'depoliticize' Russian-European relations and resolve all the issues through expert groups and technocratic exercises, Chinese officials spared no effort to demonstrate to the Russian President their attention and respects. From 2013 to 2016, the Chinese leader met President Putin 12 times (Sangar, 2018). President $\mathrm{Xi}$ was one of the few world leaders who did not participate in the fierce criticism of the Russian leader during the Brisbane Summit of the G20 (Wentour \& Doherty, 2014) and even agreed to hold an informal meeting of BRICS countries on the margins of the summit (Russia.China.org.cn, 2014). He was also one of the great power leaders who visited Moscow to attend the annual Victory Day Parade on 9 May 2015, an important symbolic event for Russia. In tune with the declarations about equality, sovereignty and trust, Beijing presented the SREB as an inclusive project and promised that part of the Silk Road would go through Russia. The evening before the above-mentioned parade, the two sides signed the document on 'Synergy between the Eurasian Economic Union and the Silk Road Economic Belt Initiative'. This prevented, or at least alleviated, the logic of geo-economic competition in bilateral relations (Makarov \& Sokolova, 2016). Several similar declarations, action plans and studies were signed and launched in 2016 and 2017. Even though there does not seem to be much substance behind these statements, they prevented an open conflict between the two powers. One could conclude that the role of personal relations and rituals helped to prevent conflict in managing significant shifts in power relations in the shared neighbourhood.

This is not to say that these factors fully neutralised the competitive logic in the bilateral relations. Some authors saw Russia's increasing military presence in the Eastern military districts as a move from a soft to a hard hedging of China (Holslag, 2016). Yet, it looks like personal relationships and Chinese sensitivity to symbolic elements of Russia's identity 
prevented an open conflict. Russian-Chinese relations remained in a paradigm of rational choice. At the time of writing, Russia is moving towards the logic of a balancing act by opening the region to third counties to maintain equality and room for manoeuvre (Efremenko, 2016). First, Moscow agreed to accepting new members into the Shanghai Cooperation Organisation, and India and Pakistan formally joined the SCO. Second, Russia agreed to strengthening the economic dimension of the Organisation, which may create a viable multilateral alternative to the SREB. Third, President Putin himself tabled the idea of a comprehensive Eurasian Partnership on the basis of the Eurasian Economic Union that would involve China, India, Pakistan, Iran and a number of CIS countries. He also mentioned that such a new bloc would be open for negotiations with Europe (Putin, 2016).

Clearly, the concept of 'Greater Eurasia' - with strong interests of other regional powers, such as Japan and South Korea - creates a more complex and broader format of great power interaction. This new format may allow more effective great power management in the dangerous period when the balance of power (hard and soft) is rapidly changing. Additionally, by opening the region to other great powers Russia also seeks to tie Central Asia to other sub-regions of Eurasia. By linking Central Asia to or even 'diluting it' in other larger regional complexes, Russia creates a better format for balancing, bargaining and trade-offs. Even if detrimental for Central Asia itself, this approach allows the great powers to avoid direct conflict in the shared neighbourhood.

\section{Conclusion}

The article sought to examine conditions under which great powers succeed or fail to shape a cooperative security agenda in their shared neighbourhoods. It has shown that ideas and in particular perceptions of various regions shape the visions which great power pursue and create cognitive lenses through which policy-makers make sense of other actors' actions. The important role of the Black Sea region and the idea of Europe in the Russian identity conditioned Moscow's willingness to play a leading role in the region and to gain Europe's recognition as security provider. At the same time, Moscow has always treated Central Asia and China as an underdeveloped periphery imbued with oriental features, a liability rather than an asset. One important generalisation is that positive emotional charge does not always automatically generate sustainable patterns of cooperation, nor does a negative background lead to conflict. Other conditions have to come into play. In the case of Central Asia, Russia's indifference to the region allowed diplomatic practice to develop a regional multilateral institution, the SCO. Moreover, it did not generate serious concerns as Chinese economic presence grew in Central Asia. This confirms the proposition of the guest editors of this special issue that indifference can be a scope condition for cooperation (Schunz, Gstöhl \& Van Langenhove, 2017).

The interplay between power and the perceptions of the neighbourhood (ideas) has also shown to be a key scope conditions for cooperation or co-opetition to emerge. As long as Europe enjoyed a relatively stronger power position (in hard and soft power terms) than Russia, Moscow mostly cooperated with Europe in the Black Sea region, even though Russian society and elites were often unhappy about it. In the early 2000s, Russia regained its material capabilities. Normally, such a fast change from power 
asymmetry to power parity is likely to generate competition. But European soft power also played an important moderating role in the change from asymmetry to parity. Russia still sought recognition by the EU and used its capabilities to attempt to 'educate' Europe into recognising Russia as an equal partner in the Black Sea region. So a mismatch between soft and hard power asymmetry can create conditions for co-opetition when great powers try to 'socialize' one another in the shared neighbourhood. The case of Sino-Russian interaction in Central Asia points to similar conditions for co-opetition. Even though China's material capabilities and economic presence in the shared neighbourhood were growing, Beijing managed to offer Moscow various benefits on a broader agenda. As a result, Moscow engaged into a policy of hedging, reaping the benefits of cooperation in other domains and providing soft resistance in the region. Another important generalisation is that both forms of co-opetition ('socialization' or 'hedging') are quite unstable. Any change even in minor factors involved in the process of interaction can lead to escalation and conflict.

The power balance and ideas can however also provide enabling conditions for conflict/cooperation. The article analysed the current state of Russian-European conflict and Sino-Russian interaction to analyse which circumstances push great powers into more conflictual and competitive forms of interaction. It argues that conflictual forms of interaction are historically contingent, resulting from a chain of subsequent events. Russia's attempt to re-invent itself as a normal West-like 'Great Power' led to a politicisation of trade issues. Europe's indifference to the Eurasian Economic Union raised suspicion towards the EU and its Eastern Partnership policy in the region. The fact that the Ukrainian revolution happened to be taking place simultaneously with the envisaged signing of the EU-Ukraine Association Agreement provoked a major post-Cold War crisis in Russian-European relations regarding their shared neighbourhood. ${ }^{7}$ It is then Putin's personality that can explain why Russia would annex and keep Crimea, despite heavy political costs. The settling of the armed conflict in Donbas points to continuity in Russian great power policies in Georgia and Moldova. This also highlights the long-term need for EU studies to balance their inward-looking tradition with an outside-in perspective (Fonck, Keuleers, \& Keukeleire, 2016).

If personality and circumstances led Russia and Europe into conflict, it was the personality of the Chinese leader Xi Jinping that pushed things into a similarly competitive direction, but also prevented great power conflict in Central Asia. Even though Chinese geoeconomic expansion into this region was obvious, previous Chinese leaders did not openly challenge Russia's symbolic domination in the region. As a result, Russia initially did not engage into region-spoiling with China. With the Xi Jinping's launch of OBOR project, Russia's role of the main 'civilizer of vast Eurasian space' has been undermined. Russia moved to the policy of balancing and region-spoiling. At the time of writing it seeks to dilute the Central Asian region in a 'Greater Eurasia'. An open conflict was prevented by close personal relations between Xi Jinping's and Putin and signs of respect displayed by China to Russia in other spheres.

The policy implications of the findings for these two cases are evident. The tactics used by China vis-à-vis Russia echo suggestions that the EU should bring the political back into its relations with neighbours (Korosteleva, 2016). Existing relations between Russian-European institutions clearly failed to prevent the crisis. Therefore, a 're-politicisation' and 're- 
personification' of this relationship, following rituals and building durable and reliable personal relations at a senior level, would be an important conflict resolution tool. ${ }^{8}$

\section{Notes}

1. The 'impressionable years' hypothesis argues that human attitudes and beliefs are mostly formed in the teenage years and early adulthood and do not change thereafter (Krosnick \& Alwin, 1989; Alwin \& Krosnick, 1991; Osborne, Sears, \& Valentino, 2011).

2. For more details on this met hodology and the role of the Black Sea region in the Russian identity, see Samokhvalov (2017).

3. The heading makes reference to the first line of "Sources of Soviet Conduct", in which $G$. Kennan claimed that it was ideology and circumstances that shaped Soviet foreign policy (X, 1947)

4. Alternative scenario had actually taken place ten years before the Euromaidan when European mediators managed to hammer a compromise during the Orange revolution.

5. I would like to thank Timofei Bordachev for this comment.

6. Even though leading European scholars sought to draw attention to such an important factor as different interaction codes pursued by new powers (Narlikar, 2010), this has not made its way into mainstream political discourse.

7. Russia did not move against Ukraine in a very similar situation during the Orange Revolution and launch of the European Neighbourhood Policy in 2003.

8. This strategy of informal interaction - labelled as 'sauna-negotiating' - worked when German chancellors Schmidt and Kohl negotiated sensitive issues with the Soviet Union (Schmidt \& di Lorenzo, 2010). I would like to thank Marc Ozawa for bringing this episode to my attention. For more on cultural aspects in energy negotiations, see Ozawa (2016).

\section{Disclosure statement}

No potential conflict of interest was reported by the authors.

\section{Funding}

This work was supported by Seventh Framework Programme: [Grant Number EU BeIPD-COFUND].

\section{Notes on contributor}

Dr Vsevolod Samokhvalov gained a BA in International Relations (Odessa, Ukraine), a MA in SouthEast European Studies (Athens) and PhD in International Relations (Cambridge). He worked as a Research Fellow at the International Center for Black Sea Studies and the European Union Institute for Security Studies. He is currently Marie-Curie Lecturer at the University of Liege, where he runs a project on Eurasian integration.

\section{References}

Alison, R. (2004). Regionalism, regional structures and security management in Central Asia. International Affairs, 80(3), 468-483.

Alison, R. (2008). Virtual regionalsim, regional structures and regime security in Central Asia. Central Asian Survey, 27(2), 185-202.

Alwin, D. A., \& Krosnick, S. J. (1991). Aging, cohorts, and the stability of sociopolitical orientations over the Life Span. American Journal of Sociology, 97(1), 169-195.

Aris, S. (2011). Eurasian regionalism: The shanghai coopration organisation. Basingstoke: Palgrave. 
Bordachev, T. (2016). To the great ocean-4: Russia's turn to the east. Moscow: Valdai Club.

Bukkvoll, T. (2016). Why putin went to war: Ideology, interests and decisionmaking in the Russian use of force in Crimea and Donbas. Contemporary Politics, 22(3), 267-282.

Chargynov, Z. (2006). Revolution, repression and re-election in 2005: China's response to political developments in Central Asia. China and Euaria Quarterly, 4(1), 31-36.

Clunan, A. (2009). The social construction of Russia's resurgence: Aspirations, identities and security interests. Baltimore: John Hopkins University Press.

Condee, N. (2009). The imperial trace: Recent Russian cinema. Oxford: Oxford University Press.

Dawisha, K. (2014). Putin's Kleptocracy: Who owns Russia? New York, NY: Simon\&Shuster.

Dragneva, R., \& Wolczuk, K. (2013). Eurasian economic integration: Institutions, promises and faultlines. London: London School of Economic and Political Science.

Efremenko, D. (2016, November 28). Rozhdenie Bolshoi Evrazii. Russia in Global Affairs, vol. 6.

Fonck, D., Keuleers, F., \& Keukeleire, S. (2016). Beyond EU navel-gazing: Taking stock of EU-centrism in EU foreign policy studies. Conflict and Cooperation, 51(3), 345-364.

Gabuev, A. (2015). A "soft alliance"? Russia-China relations after Ukraine crisis. London: European Council for Foreign Relations.

Galenovich, Y. (2017). e-reading.clun. Consulted in 2017, at http://www.e-reading.club/bookreader. php/13134/Galenovich_-_Rossiya_i_Kitaii_v_XX_veke_

Gessen, M. (2013). The Man without Fase: The unlikely rise of Vladimir Putin. New York, NY: Riverhead Books.

Gilespe, D. (2003). Russian cinema. Harlow: Pearson Education Longman.

Goetz, E. (2016). Putin, the state, and War: The causes of russia's near abroad assertion revisited. International Studies Review, 1-26.

Hansen, L. (2009). Security as practice: Discourse analysis and the Bosnian War. Abington: Routledge. Hill, W. (2012). Russia, the near abroad, and the West: Lessons from the Moldova-Transdniestries conflict. Washington: Wilson Centre.

Hill, F., \& Gaddy, C. G. (2012). Mr. Putin: Operative in the Kremlin. Washington, DC: Brookings Institution Press.

Holslag, J. (2016). Hedging the hard way: Russia's response to world disorder. World Affairs, 2(2), 165176.

Hopf, T. (1999). Understandings of Russian foreign policy. University Park: Pennsylvania State University Press.

Hopf, T. (2002). Social construction of international politics. Ithaca: Cornell University Press.

Kazharskiy, A. (2013). Eurasian regionailsm as an identitary enterprise: Represenations of European other in Russian discourse on Eurasian integration. Tartu: Centre for EU-Russia Studies.

Korolev, A. (2016). Systemic balancing and regional Hedging: China-Russia relations. The Chinese Journal of International Politics, 9(4), 1-23.

Korosteleva, E. (2016). Eastern partnership and the Eurasian Union: bringing 'the political' back in the eastern region. European Politics and Society, 17, 67-81.

Krosnick, J. A., \& Alwin, F. D. (1989). Aging and susceptibility to attitude change. Journal of Personality and Social Psychology, 57(3), 416-425.

Latynina, Y. (2013, February 9). Kod Dostupa Programme Echo of Moscow Radiostation. Moscow. Récupéré sur http://echo.msk.ru/programs/code/1007958-echo/

Makarov, I., \& Sokolova, A. K. (2016). Sopriazhenie Evraziyskoi Integratii I Ekonomicheskogo Poiasa Shelkovogo Puti: vozmozhnosti dlia Rossii. International Organizations Journal, 11(2), 40-57.

Marsh, S., \& Rees, W. (2012). The European Union in the security of Europeș from cold War to terror War. London: Routledge.

Molchanov, M. (2015). Eurasian regionalism and Russian foreign polocy. Burlington: Ashgate.

Morozov, V. (2015). Russia's postcolonial identity: A subaltern empire in a eurocentric world. Basingstoke: k: Palgrave.

Narlikar, A. (2010). New powers; how to become one and how to manage them. New York, NY: Columbia University Press.

Osborne, D., Sears, O. D., \& Valentino, A. N. (2011, February). The End of the solidly democratic south: The impressionable-years hypothesis. Political Psychology, 32(1), 81-108. 
Ozawa, M. (2016, November). Trust and European-Russian Energy Relations: The Cases of GermanRussian and British-Russian Cooperation in Oil and Natural Gas. PhD Thesis. University of Cambridge, Cambridge.

Pandey, S. K. (2007). Asia in the debate on Russian identity. International Studies, 44(4), 317-337.

Pankratova, A. (Ed.). (1947). Istoria SSSR: Chast Pervaya: Uchebnik dlia 8-ogo klassa sredney shkoly. Moscow: Uchpedgis.

Potemkin, V. (Ed.). (1941). Istoria Diplomatii (History of diplomacy), vol. I. Moscow: OGIZ.

Press Service, G. o. (2011). Prime minister Vladimir Putin visits the 14th international bike show in Sebastopol. Moscow: Press-Release.

Putin, V. (2003, May 16). Annual address to the federal assembly of the Russian Federation. Moscow. Retrieved from http://en.kremlin.ru/events/president/transcripts/21998

Putin, V. (2016, June 17). Plenary session of St Petersburg international economic forum. Saint Petersburg. Retrieved from http://en.kremlin.ru/events/president/news/52178

Romanova, T. (2012, October). Neoclassical realism and today's russia. Russia in Global Affairs, 51(3). Rose, G. (1998). Neoclassical realism and theories of foreign policy. Wolrd Politics, 51(1), 144-72.

Russia.China.org.cn. (2014, November 16). Xi Jingpin. Consulted on September 11, 2017, at http:// russian.china.org.cn/exclusive/txt/2014-11/16/content_34060936.htm

Saipov, Z. (2015). Chinese understanding of Uzbekistan's foreign and domestic policy needs sustains mutual political trust. Eurasia Daily Monitor, 9(175).

Sakwa, R. (2015). Frontline Ukraine. Crisis in the borderlands. London: B. Tauris.

Samokhvalov, V. (2017). Russian-European relations in the Balkans and Black Sea region: Great power identity and idea of Europe. Basingstoke: Palgrave.

Sangar, K. (2018). Russia and China as the Yin-and-yang of 21st century Eurasia? In D. Lane, \& G. Zhu (Eds.), Changing regional alliance for China and the west. Ladham: Rowman\&Littlefield.

Schmidt, H., \& di Lorenzo, G. (2010). Auf eine Zigarette mit Helmut Schmidt. Köln: KiWi-Taschenbuch.

Schunz, S., Gstöhl, S., \& Van Langenhove, L. (2017). Between cooperation and competition: major powers in shared neighbourhoods. Contemporary Politics, 24(1), 1-13. doi:10.1080/13569775. 2017.1408174

Singh, P., Chaterjee, S., \& Sengupta, A. (2014). Beyond strategies: Cultural dynamics in Asian connections. New Delhi: KW Publisher.

Staples, J. (1993). Soviet Use of corruption purges as a control mechanism: The Uzbekistan case. Past Imperfect (edmonton, Alta ), 2, 29-48.

Titarenko, M. (2014). Rossiya i Kitay: Strategicheskoe partnerstvo i Vyzovy Vremeni. Moscow: Forum. UN. (1997, May 20). www.un.org.

Weitz, R. (2003). Why russia and China have not formed an anti-American alliance. Washington, DC: Hudson Institute. Récupéré sur https://www.hudson.org/research/3758-why-russia-and-chinahave-not-formed-an-anti-american-alliance

Wentour, P., \& Doherty, J. (2014, November 16). Vladimir Putin leaves G20 after leaders line up to browbeat him over Ukraine. Guardian. Récupéré sur https://www.theguardian.com/world/2014/ nov/16/vladimir-putin-leaves-g20-after-leaders-line-up-to-browbeat-him-over-ukraine

Wetiz, R. (2012). The rise and Fall of Medvedev's European Seucirty Treaty. Washington: German Marshall Fund of the United States.

White, S., \& Feklyunina, V. (2014). Identities and foreign policies in Rusia, Ukraine and Belarus: The other Europes. Basingstoke: Palgrave.

Wigell, M., \& Vihma, A. (2016). Geopolitics versus Geo-economics: The case of Russia's Geostrategy and its effects on the EU. International Affairs, 92(3), 605-627.

Wilson, A. (2014). Ukraine crisis: What it means for the west. New Haven: Yale University Press.

X. (1947). Sources of soviet conduct. Foreign Affairs, 25(4), 266-284.

Zhukov, E. (Ed.). (1955). Vsemirnaya Istoria v Desiati Tomakh, vol. 1. Moscow: Akademiya Nauk SSSR. 